Article

\title{
Azima tetracantha Leaf Methanol Extract Inhibits Gastric Cancer Cell Proliferation through Induction of Redox Imbalance and Cytochrome C Release
}

\author{
Young Ock Kim ${ }^{1}$, Arunaksharan Narayanankutty ${ }^{2, *}$, Aswathi Moothakoottil Kuttithodi ${ }^{2}$, Hak-Jae Kim ${ }^{1, *(D),}$ \\ Sae Won $\mathrm{Na}^{3}$, Krishnaprasad Kunnath ${ }^{4}$, Rajakrishnan Rajagopal ${ }^{5}$ and Ahmed Alfarhan ${ }^{5, *}$ \\ 1 Department of Clinical Pharmacology, College of Medicine, Soonchunhyang University, \\ Cheonan 31538, Korea; hak3962@sch.ac.kr \\ 2 PG and Research Department of Zoology, Division of Cell and Molecular Biology, \\ St. Joseph's College Devagiri (Autonomous), Kozhikode 683581, India; abcaswathi@gmail.com \\ 3 The Comfort Animal Hospital, Seongbuk-gu, Sungin-ro-50, Seoul 04339, Korea; nsw0718@gmail.com \\ 4 Department of Pharmacology, Devaki Amma Memorial College of Pharmacy, Malapuram 673634, India; \\ Krishnaprasadk91@gmail.com \\ 5 Department of Botany and Microbiology, College of Science, King Saud University, P.O. Box 2455, \\ Riyadh 11451, Saudi Arabia; rrajagopal@ksu.edu.sa \\ * Correspondence: arunaksharan1990@gmail.com (A.N.); hak3862@sch.ac.kr (H.-J.K.); \\ alfarhan@ksu.edu.sa (A.A.); Tel.: +91-984-779-3528 (A.N.)
}

check for updates

Citation: Kim, Y.O.; Narayanankutty, A.; Kuttithodi, A.M.; Kim, H.-J.; Na, S.W.; Kunnath, K.; Rajagopal, R.; Alfarhan, A. Azima tetracantha Leaf Methanol Extract Inhibits Gastric Cancer Cell Proliferation through Induction of Redox Imbalance and Cytochrome C Release. Appl. Sci. 2022, 12, 120. https://doi.org/ 10.3390/app12010120

Academic Editors:

Emanuele-Salvatore Scarpa and

Marca Giammanco

Received: 19 July 2021

Accepted: 16 December 2021

Published: 23 December 2021

Publisher's Note: MDPI stays neutral with regard to jurisdictional claims in published maps and institutional affiliations.

Copyright: (C) 2021 by the authors. Licensee MDPI, Basel, Switzerland. This article is an open access article distributed under the terms and conditions of the Creative Commons Attribution (CC BY) license (https:// creativecommons.org/licenses/by/ $4.0 /)$.
Featured Application: The antiproliferative effects of Azima tetracantha support its traditional uses; additionally, it may emerge as a possible source of promising anticancer biomolecules in the future.

\begin{abstract}
Azima tetracantha is a traditionally used medicinal plant in the Ayurvedic system and folk medicines. The plant has been used for various purposes including inflammatory ailments, arthritis, and various types of toxicities. There are no available reports on its anticancer activity; hence, the study aimed to evaluate its anti-proliferative potential in gastric cancer cells (AGS and KATO III). We observed a dose-dependent decrease in cell proliferation in both the gastric cancer cells; furthermore, a concomitant reduction in the cellular antioxidant status was observed. Pre-treatment with $A$. tetracantha methanol extract showed a significant reduction in intracellular glutathione levels, and subsequently raised thiobarbituric acid reactive substances. Together with this, a significant increase in the cytochrome c release was noted in A. tetracantha treated cells, alongwith an increase in the expression of pro-apoptotic genes such as BAX, CASP3, CASP7 and APAF1. Furthermore, RTqPCR analysis indicated an increased expression of the anti-apoptotic gene BCL2 in a dosedependent manner. In addition, to confirm the role of reactive oxygen species in the proliferation inhibition, DCFH-DA-based analysis was carried out, where a dose-dependent increase in ROS levels was observed in these cells. Overall, the study confirms the anticancer efficacy of A. tetracantha leaf methanol extract mediated through the induction of redox imbalance and cytochrome c release.
\end{abstract}

Keywords: Azima tetracantha; gastric cancer; apoptosis; redox imbalance; cytochrome c

\section{Introduction}

Gastric cancer or stomach cancer is one of the leading cancers in males which accounts for considerable mortality globally. Genetic factors are an important regulator of the carcinogenic responses in the stomach; among these, the most prominent is the mutations of a tumor suppressor gene, $\mathrm{CDH1}$, that encodes the E-cadherin-class proteins [1]. Apart from these factors, infections of Helicobacter pylori and certain human papillomaviruses are also reported to have a significant association with gastric carcinoma [2,3]. Dietary habits and other infections are also known to be associated with the incidence of the onset 
and advancement of gastric neoplasms [4]. Increased consumption of fatty foods [5], and diets rich in sugars [6] and salts [7] are reported to increase the incidence of gastric cancer. In addition, several oncogenic signaling pathways are also found to be upregulated in gastric cancers; these include the TGF-beta signaling family [8], receptor tyrosine kinase family proteins [9], especially epidermal growth factor receptor [10], and various growth factors [11]. According to recent reports from the USA, gastric cancer is the fifth most common cancer with an annual occurrence of over 1 lakh new cases per year and accounts for about 7 lakh deaths annually [12,13]. The overall five-year survival rates of gastric cancer are also estimated to be lower with an average of $31 \%$ for metastatic cases and less than $67 \%$ for non-metastatic cases [14]. Hence, the treatment of gastric cancer is of greater importance and therefore various therapeutic strategies are being employed for this tumor [15]. Among the forerunners of cost-effective anticancer drugs, the natural products isolated from plants are the most important compounds.

Various plants are being utilized for cancer prevention and therapy by traditional practitioners in Ayurvedic and Chinese medicines; however, the main limitation of their application is the reduced scientific support for their efficacy. The Western Ghats are an important source of such medicinal plants and the present study evaluated the possible application of a widely used anti-inflammatory medicinal plant Azima tetracantha for its possible application in gastric cancer control. The plant is widely used in Ayurvedic medicines and folk medicinal systems as a dietary supplement [16]; however, limitted studies have analyzed their application as a dietary ingredient. The plant is a rich source of a bioactive compound called friedelin; the antioxidant and anti-inflammatory properties of the isolated friedelin from $A$. tetracantha have also been reported [16,17]. The gastroprotective effect of this plant, whereby it inhibits gastric ulceration and inflammatory damages in animal models, has also been reported [18]. However, there are no further reports available on the plant for further anticancer properties or other biological efficacies. It is noteworthy that the plant, being a dietary supplement and gastro-protective agent, may be useful, and it may emerge as an anticancer agent against gastric cancer.

\section{Materials and Methods}

\subsection{Laboratory Reagents, Chemicals, and Other Supplies}

All chemicals used for routine laboratory biochemical assays were purchased from SRL Pvt. Ltd. (Mumbai, Maharashtra, India) and were of reagent-grade quality. The reagents and culture media components for cell culture were obtained from Sigma Aldrich (St. Louis, MI, USA) and Thermo Scientific (Waltham, MA, USA); all these reagents were compatible with cell culture or had a grade of molecular biology.

Gastric cancer cells Kato-III and AGS, as well as non-cancerous human cell line (HEK293), were provided by the Department of Biotechnology, National Centre for Cell Science, Pune, India. The cells were maintained in quarantine for 1 week and observed for any signs of contamination or other infections. The cells were maintained in standard conditions.

\subsection{Extraction of Azima Tetracantha and Phytochemical Analysis}

Authenticated specimens of Azima tetracantha leaves were obtained from Dr. Anisha Sathyan M., Malabar Christian College, Calicut, Kerala, India. The leaves were cleaned and dried before powdering and were extracted using the Soxhlet apparatus and serially extracted using different solvents such as petroleum ether, chloroform, acetone, and methanol for a period of $6 \mathrm{~h}$. All the solvents used were of HPLC-grade quality to ensure accuracy in LC/MS analysis. The phenolic content [19] and total flavonoids [20] in the extracts were quantified using the already mentioned procedures.

Liquid chromatography/mass spectroscopy studies on the phytochemical composition of the extract were conducted according to the methods described in our previously published article [21].

The extracted materials were suitably dissolved in solvents such as dimethyl sulfoxide (DMSO) and for each assay, a DMSO control was maintained. The final value was calculated 
by normalizing with this value. Furthermore, wherever it is necessary, the solvent blank was applied to normalize the issue.

\subsection{Efficacy of A. tetracantha Leaf Methanol Extract on the Neoplastic Cell Lines}

The noncancerous human cell line HEK293 and neoplastic cell lines of gastric origin were selected (AGS and Kato-III cells). The cells were cultivated in the complete DMEM media supplemented under defined atmospheric conditions. The cells upon attachment were exposed to different doses of $A$. tetracantha extract. The toxicity was determined as percentage cell death by comparison with the untreated HEK293/Kato-III/AGS cells using the MTT assay [22] using the standard formula;

$$
\% \text { Cell death }=\frac{\text { Absorbance of Control }- \text { Absorbance of Sample }}{\text { Absorbance of Control }} \times 100
$$

In order to provide more clarity on the role of reactive oxygen species on the cytotoxicity, the cells were pre-treated with $0.125 \mathrm{mM}$ reduced glutathione or $1 \mathrm{mM}$ buthionine sulfoximine (BSO) to observe the changes in cell viability.

\subsection{RTqPCR Analysis}

The different gastric cancer cells were treated with the IC50 dose and sub-lethal doses of $A$. tetracantha for $24 \mathrm{~h}$. The cells were collected by mechanical cell scrapers and they were directly used for the synthesis of cDNA using standard kits available by strictly adhering to the producer's directions (CellAmp ${ }^{\mathrm{TM}}$ cell to cDNA kit, Takara Bio, Bangaluru, India). The gene expression profiling was carried out using qPCR (Applied Biosystem 7500, Applied Biosystems) with selected primers (Table 1). The fold change in the expression of individual genes was calculated from the CT values using the $2^{-\Delta \Delta C T}$ method with respect to the untreated control cells; the beta actin gene was used as a housekeeping gene as per previously published methods [23].

Table 1. The primer sequences of various genes involved in apoptosis and anti-apoptotic genes; ACTB ( $\beta$-actin) was used as a housekeeping gene.

\begin{tabular}{|c|c|c|}
\hline Gene & Direction & Sequence \\
\hline \multirow{2}{*}{ CASPASE-3 } & Forward & 5'-GCTGGATGCCGTCTAGAGTC-3' \\
\hline & Reverse & 5'-ATGTGTGGATGATGCTGCCA-3' \\
\hline \multirow{2}{*}{ CASPASE-7 } & Forward & 5'-GGGCCCATCAATGACACAGA-3' \\
\hline & Reverse & 5'-GTCTTTTCCGTGCTCCTCCA-3' \\
\hline \multirow{2}{*}{ APAF-1 } & Forward & 5'-TCTTCCAGTGGTAAAGATTCAGTT-3' \\
\hline & Reverse & 5'-TTGCGAAGCATCAGAATGCG-3' \\
\hline \multirow{2}{*}{ BAX } & Forward & $5^{\prime}$-GAGCTAGGGTCAGAGGGTCA-3' \\
\hline & Reverse & 5'-CCCCGATTCATCTACCCTGC-3' \\
\hline \multirow{2}{*}{ BCL2 } & Forward & 5'-ACCTACCCAGCCTCCGTTAT-3' \\
\hline & Reverse & 5'-GAACTGGGGGAGGATTGTGG-3' \\
\hline \multirow{2}{*}{$\beta$-ACTIN } & Forward & 5'-ACTACCTCATGAAGATCCTC-3' \\
\hline & Reverse & $5^{\prime}$-TAGAAGCATTTGCGGTGGACGATGG-3' \\
\hline
\end{tabular}

\subsection{Estimation of Reactive Oxygen Species by DCFH and Cytochrome-C Release}

The intracellular reactive oxygen species levels were determined by $2^{\prime}, 7^{\prime}$-dichlorofluorescein diacetate (DCFH-DA) (Thermo Fisher Scientific, Waltham, MA, USA) as described by the producer's manual. DCFH-DA fluorescence was determined using a fluorescence spectrophotometer at Ex/Ew wavelength of 485/520 nm. Cytochrome c release was estimated using standard kits according to the manufacturer's instructions (GeneTex, India) and the results are represented in relative fluorescence units. 


\subsection{Statistical Analysis}

Results of the anticancer study and qPCR analysis are represented as Mean \pm SD of six independent observations. The test of significance was carried out using a oneway analysis of variance, followed by a Tukey post hoc test (GraphPad Prism version 7.0, La Jolla, CA, USA).

\section{Results}

\subsection{Quantitative and LCMS-Based Screening of Phytoconstituents}

The quantitative determination of phenol products in the different extracts of A. tetracantha was determined spectrophotometrically. Among these, methanol extract had higher phenol derivatives $(277.35 \pm 10.4 \mathrm{mg} \mathrm{GAE} / \mathrm{g})$ followed by acetone extract $(175.34 \pm 8.8 \mathrm{mg} \mathrm{GAE} / \mathrm{g})$. In the petroleum ether extract, the lowest recording of the phenol compounds was observed. Corroborating this, the flavonoid content was also higher in the methanol and acetone extracts (Table 2). The liquid chromatographic analysis coupled with the mass spectra indicated the presence of various phenolic acids and also complex flavonoid compounds in the methanol extract (Supplementary Material S1).

Table 2. The quantitative analysis of the predominant phytoconstituents of the different extracts of $A$. tetracantha by spectrophometric methods.

\begin{tabular}{ccccc}
\hline Parameters & Petroleum Ether & Chloroform Extract & Acetone Extract & Methanol Extract \\
\hline Total phenols (TPC) & $72.35 \pm 4.3$ & $92.22 \pm 4.1^{\mathrm{a}}$ & $175.34 \pm 8.8^{\mathrm{a}, \mathrm{b}}$ & $277.35 \pm 10.4^{\mathrm{a}, \mathrm{b}, \mathrm{c}}$ \\
Total flavonoids (TF) & $11.05 \pm 1.5$ & $13.19 \pm 2.6^{\mathrm{a}}$ & $29.67 \pm 3.4^{\mathrm{a}, \mathrm{b}}$ & $48.06 \pm 3.85^{\mathrm{a}, \mathrm{b}, \mathrm{c}}$ \\
\hline
\end{tabular}

a_-indicates significant variation with petroleum ether, ${ }^{b}$ _indicates significant variation with chloroform c_-indicates significant variation with acetone extracts.

\subsection{Anti-Proliferative Activity of A. tetracantha Methanol Extract and Changes in the Cellular Redox Status}

Figure 1a indicates the anti-proliferative potential of the extract in both Kato-III and AGS cells in a dose-dependent manner over $48 \mathrm{~h}(p<0.01)$. However, the toxicity was lower in the non-cancerous human embryonic kidney cells, possibly indicating its selective anticancer properties (Figure 1a). The IC50 values of the extract in Kato-III cells was found to be $44.69 \pm 1.09 \mu \mathrm{g} / \mathrm{mL}$ and the same in AGS cells was $58.04 \pm 1.32 \mu \mathrm{g} / \mathrm{mL}$; however, the cytotoxicity was significantly lower $(p<0.001)$ in non-cancerous HEK293 cells with an IC50 value of $109.75 \pm 1.85 \mu \mathrm{g} / \mathrm{mL}$. Furthermore, the addition of reduced glutathione to the cells along with $A$. tetracantha extracts induced a reduction in the toxic effect of the extract; furthermore, the addition of $\mathrm{BSO}$, an inhibitor of glutathione biosynthesis, enhanced the cytotoxicity of the plant extract in cells (Supplementary Material S2a,b).

Additionally, when the A. tetracantha is exposed to the HEK293 cells at dose of 45 and $60 \mu \mathrm{g} / \mathrm{mL}$ (close to the IC50 doses in Kato-III and AGS cells), the observed \% cell death was nearly $18 \%$ and $25 \%$, respectively; this in turn confirms the significantly lower toxicity of A. tetracantha in the cancerous cells (Supplementary Material S3). As indicated in Table 3, the cellular antioxidant levels and lipid peroxidation indicators in the cells (AGS and Kato-III) exposed to different concentrations of $A$. tetracantha methanol extract were altered. The catalase activity was significantly increased in the different doses of $A$. tetracantha methanol extract $(p<0.05)$; on the contrary, we observed a significant and dose-dependent reduction in reduced glutathione (GSH). Similarly, a corresponding increase in the lipid peroxidation products (TBARS and conjugated dienes) was observed after the different doses of $A$. tetracantha methanol extract. 

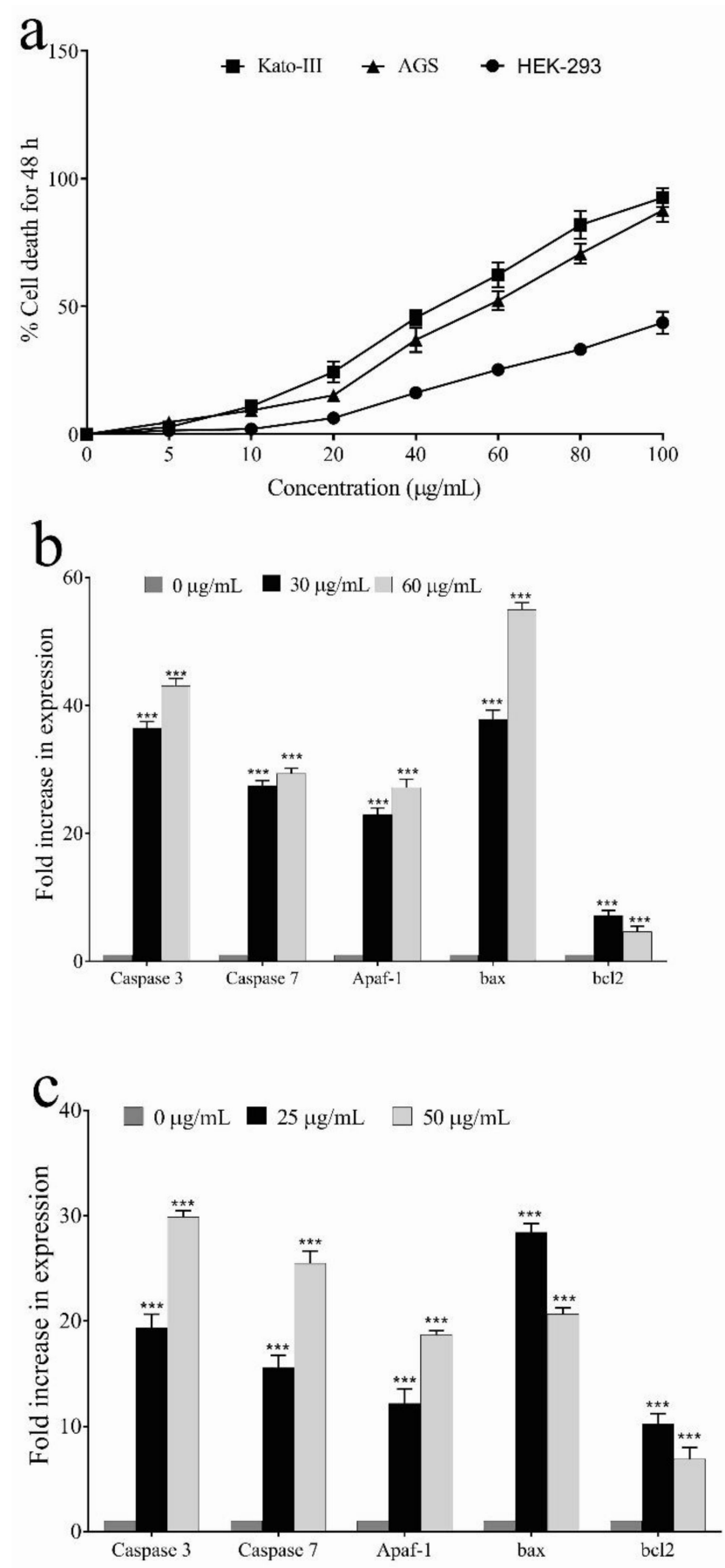

Figure 1. Inhibitory potential of $A$. tetracantha on the proliferation of neoplastic cells of human gastric origin (a). qPCR-based detection of apoptotic gene expression in the different gastric neoplastic cells: Kato III (b) and AGS cells (c). The fold change in expression of each gene was calculated by the $2^{-\Delta \Delta \mathrm{CT}}$ method in comparison with the untreated control cells. ( ${ }^{* * *}$ indicate $\left.p<0.001\right)$. 
Table 3. Cellular level of non-enzymatic redox markers and radical scavenging enzyme activities in gastric neoplastic cells treated with varying doses of methanol extract of Azima tetracantha. The * indicates the significance variation by $p<0.05,{ }^{* *}$ indicates the variation of $p<0.01$ and ${ }^{* * *}$ represents variation of $p<0.001$.

\begin{tabular}{cccccc}
\hline Cell & Dosage & $\begin{array}{c}\text { Catalase } \\
(\mathbf{U} / \text { mg Protein) }\end{array}$ & $\begin{array}{c}\text { Reduced Glutathione } \\
(\boldsymbol{\mu} \text { moles/mg Protein) }\end{array}$ & $\begin{array}{c}\text { Thiobarbic Acid } \\
\text { Reactive Substances } \\
(\text { nmoles/mg Protein) }\end{array}$ & $\begin{array}{c}\text { Conjugated Dienes } \\
(\text { nmoles/mg Protein) }\end{array}$ \\
\hline \multirow{2}{*}{ Kato-III } & Untreated & $21.6 \pm 1.03$ & $3.77 \pm 0.19$ & $1.35 \pm 0.11$ & $22.5 \pm 2.4$ \\
& $25 \mu \mathrm{g} / \mathrm{mL}$ & $34.2 \pm 1.19^{*}$ & $3.08 \pm 0.22^{*}$ & $3.21 \pm 0.41^{*}$ & $66.3 \pm 2.7^{*}$ \\
& $50 \mu \mathrm{g} / \mathrm{mL}$ & $51.7 \pm 2.04^{* *}$ & $2.62 \pm 0.18^{* * *}$ & $4.64 \pm 0.34^{* *}$ & $82.8^{* *} \pm 3.1^{* * *}$ \\
\hline \multirow{2}{*}{ AGS } & Untreated & $44.1 \pm 2.82$ & $2.51 \pm 0.26$ & $2.46 \pm 0.20$ & $36.1 \pm 2.9$ \\
& $30 \mu \mathrm{g} / \mathrm{mL}$ & $68.3 \pm 3.55^{*}$ & $2.11 \pm 0.19^{*}$ & $3.65 \pm 0.16^{*}$ & $55.7 \pm 2.6^{*}$ \\
& $60 \mu \mathrm{g} / \mathrm{mL}$ & $94.5 \pm 3.9^{* * *}$ & $1.69 \pm 0.33^{* *}$ & $4.51 \pm 0.12^{* *}$ & $79.3 \pm 4.5^{* * *}$ \\
\hline
\end{tabular}

\subsection{RTqPCR, Cytochrome C Release, Reactive Oxygen Species Evaluation}

The molecular mechanisms modulated by Azima tetracantha natural extract were estimated utilizing qPCR-mediated analysis (Figure $1 \mathrm{~b}$ ), reactive oxygen species, and cytochrome c release. Our results show a significant increase in the CASP3, CASP7, APAF1 and BAX genes in A. tetracantha $(p<0.05)$ methanol-extract-treated AGS and Kato-III cells (Figure 1b,c). Notably, we observed only a slight increase in the expression levels of the anti-apoptotic gene BCL2 after the A. tetracantha methanol extract treatment. The release of mitochondrial cytochrome $\mathrm{c}$ was found to be increased in the cells treated with A. tetracantha-extract-treated cells (Figure 2). Together with this, the intracellular level of reactive oxygen species was also increased dose dependently $(p<0.05)$ in both the cells (Figure 2).
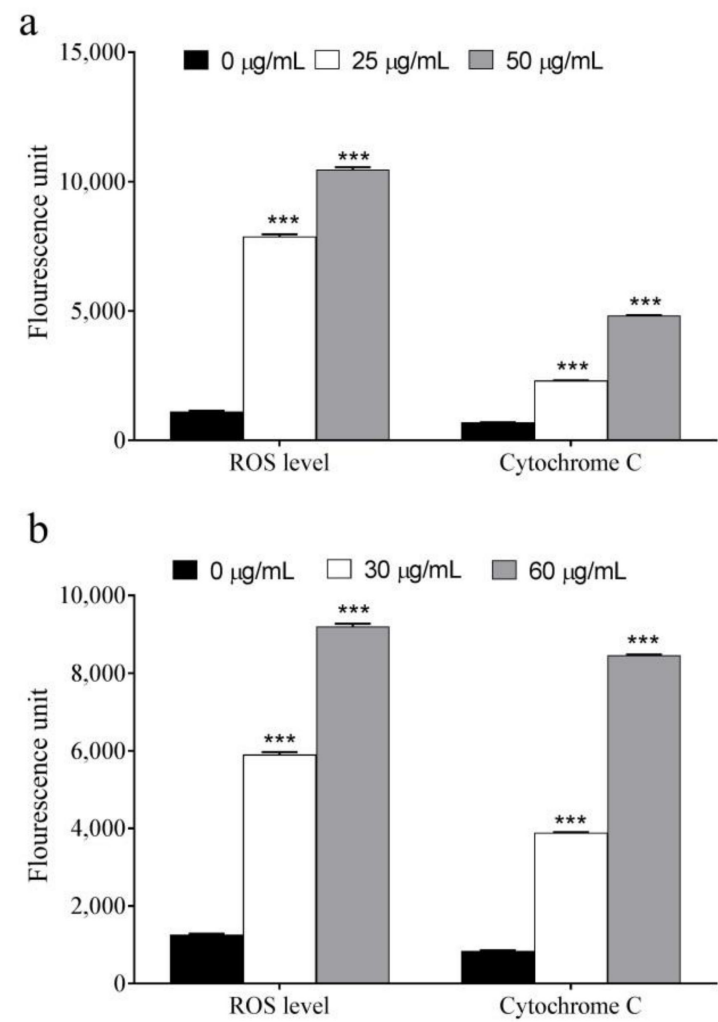

Figure 2. Changes in the reactive oxygen species levels and cytochrome C levels of Kato-III (a) and AGS cells (b) after $A$. tetracantha leaf methanol extract treatment. (*** indicate $p<0.001)$. 


\section{Discussion}

The plant Azima tetracantha is widely used in traditional medicinal systems including Ayurvedic and Chinese medicines.In addition, the plant decoctions are used as dietary supplements by various tribes in India. However, few studies indicate the scientific evidence of the biological and pharmacological properties of the plant. The present study evaluates the potential antiproliferative role of $A$. tetracantha extract against different gastric cancer cells and its possible mechanism of action.

Among the different solvents, the methanol extract showed the highest levels of polyphenols and flavonoids. In addition, the LCMS profiling indicated the presence of different polyphenols comprising simple phenolic acids and complex dietary polyphenols. Previous results by Bennett et al. [24] indicate the presence of flavonoid compounds and glucosinolates in A. tetracantha tissues. Notably, the extract showed significant anticancer potential against the two gastric cancer cell lines, AGS and Kato-III. To provide the mechanistic basis of action, the expression of apoptotic genes including CASP3, CASP7, APAF1 and BAX was evaluated. These genes are known to be associated with apoptotic cell death in various cell types, and the changes in their expression levels modulate the mitochondrial-mediated apoptosis in cells $[25,26]$. Furthermore, the proteins Apaf- 1 and cytochrome c, together with Caspase 9, are involved in the formation of the apoptosome complex via the intrinsic pathway [27]. Interestingly, our data show that the A. tetracanthaextract-mediated increase in BAX expression levels in both Kato-III and AGS cancer cells was higher than the increase obtained for BCL2 mRNA levels, leading to an increase in the BAX/BCL2 mRNA ratio, which has already been used to explain the anticancer effects of flavanols on breast and prostate cancer cells [28]. The cytochrome $\mathrm{c}$ release from damaged mitochondrial membrane was also found to be increased in those cancer cells exposed to different doses of $A$. tetracantha methanol extract; in addition, the cellular reactive oxygen species levels were also found to be upregulated in these cells. It is thus possible that the ROS-mediated mitochondrial damage performed by $A$. tetracantha extract could explain the anti-proliferative activity of the plant.

A. tetracantha is known to possess antioxidant potentials [16] and to inhibit inflammatory signaling [29] and cancer cell proliferation [30]; hence, together with these antioxidant and anti-inflammatory properties, the anticancer property may enhance the functional value of the plant.

\section{Conclusions}

The results indicate the anti-neoplastic applications of the $A$. tetracantha extracts in gastric cells. The action is mainly mediated through the induction of oxidative radicals and redox imbalance in these cells.

Supplementary Materials: The following supporting information can be downloaded at: https: / / www.mdpi.com/article/10.3390/app12010120/s1, Supplementary Material S1: Composition of the polyphenols in methanolic extract of Azima tetracantha leaves analyzed by LC-MS. Supplementary Material S2: The effect of Azima tetracantha extract alone treatment (a), A. tetracantha co-treated with glutathione biosynthesis inhibitor- buthionine sulfoximine (BSO) on the cell death induced by Azima tetracantha extract (b). Supplementary Material S3. The comparison of \% cell death at individual doses of Azima tetracantha extract treated cells; the comparison was made with the non-cancerous cell (HEK293) to the AGS and Kato-III cells. Supplementary Material S4. The effect of Azima tetracantha extract alone treatment and the BSO co-treatment on the cell death of Kato-III and AGS cells.

Author Contributions: Conceptualization, A.N., H.-J.K. and A.A.; methodology, Y.O.K. and A.N.; software, A.N.; validation, K.K. and R.R.; formal analysis, S.W.N. and A.M.K.; investigation, A.M.K.; resources, A.N.; data curation, A.N. and R.R.; writing-original draft preparation, S.W.N., R.R., H.-J.K., Y.O.K. and A.N.; writing-review and editing, A.N. and A.A.; supervision and project administration, A.N.; funding acquisition, A.A. and H.-J.K. All authors have read and agreed to the published version of the manuscript. 
Funding: The research work was partially supported by King Saud University, Riyadh, Saudi Arabia through Researchers Supporting Project No: RSP 2021/11.

Institutional Review Board Statement: Not applicable.

Informed Consent Statement: Not applicable.

Data Availability Statement: Data may be made available on valid request to the corresponding author.

Acknowledgments: The authors acknowledge King Saud University, Riyadh, Saudi Arabia for funding this research through Researchers Supporting Project No: RSP 2021/11.

Conflicts of Interest: The authors declare no conflict of interest.

\section{References}

1. Selvanathan, A.; Nixon, C.Y.; Zhu, Y.; Scietti, L.; Forneris, F.; Uribe, L.M.M.; Lidral, A.C.; Jezewski, P.A.; Mulliken, J.B.; Murray, J.C.; et al. CDH1 Mutation Distribution and Type Suggests Genetic Differences between the Etiology of Orofacial Clefting and Gastric Cancer. Genes 2020, 11, 391. [CrossRef]

2. Díaz, P.; Valenzuela Valderrama, M.; Bravo, J.; Quest, A.F.G. Helicobacter pylori and Gastric Cancer: Adaptive Cellular Mechanisms Involved in Disease Progression. Front. Microbiol. 2018, 9, 5. [CrossRef] [PubMed]

3. Zeng, Z.-M.; Luo, F.-F.; Zou, L.-X.; He, R.-Q.; Pan, D.-H.; Chen, X.; Xie, T.-T.; Li, Y.-Q.; Peng, Z.-G.; Chen, G. Human papillomavirus as a potential risk factor for gastric cancer: A meta-analysis of 1,917 cases. OncoTargets Ther. 2016, 9, 7105-7114. [CrossRef] [PubMed]

4. Roy, N.; Davis, S.; Narayanankutty, A.; Nazeem, P.; Babu, T.D.; Abida, P.; Valsala, P.; Raghavamenon, A.C. Garlic Phytocompounds Possess Anticancer Activity by Specifically Targeting Breast Cancer Biomarkers-an in Silico Study. Asian Pac. J. Cancer Prev. 2016, $17,2883-2888$.

5. Han, J.; Jiang, Y.; Liu, X.; Meng, Q.; Xi, Q.; Zhuang, Q.; Han, Y.; Gao, Y.; Ding, Q.; Wu, G. Dietary Fat Intake and Risk of Gastric Cancer: A Meta-Analysis of Observational Studies. PLoS ONE 2015, 10, e0138580. [CrossRef]

6. Sieri, S.; Agnoli, C.; Pala, V.; Grioni, S.; Brighenti, F.; Pellegrini, N.; Masala, G.; Palli, D.; Mattiello, A.; Panico, S.; et al. Dietary glycemic index, glycemic load, and cancer risk: Results from the EPIC-Italy study. Sci. Rep. 2017, 7, 9757. [CrossRef]

7. Kim, J.; Oh, A.; Truong, H.; Laszkowska, M.; Camargo, M.C.; Abrams, J.; Hur, C. Low sodium diet for gastric cancer prevention in the United States: Results of a Markov model. Cancer Med. 2021, 10, 684-692. [CrossRef]

8. Ishimoto, T.; Miyake, K.; Nandi, T.; Yashiro, M.; Onishi, N.; Huang, K.K.; Lin, S.J.; Kalpana, R.; Tay, S.T.; Suzuki, Y.; et al. Activation of Transforming Growth Factor Beta 1 Signaling in Gastric Cancer-associated Fibroblasts Increases Their Motility, via Expression of Rhomboid 5 Homolog 2, and Ability to Induce Invasiveness of Gastric Cancer Cells. Gastroenterology 2017, 153, 191-204. [CrossRef]

9. Du, Z.; Lovly, C.M. Mechanisms of receptor tyrosine kinase activation in cancer. Mol. Cancer 2018, 17, 58. [CrossRef]

10. Adashek, J.J.; Arroyo-Martinez, Y.; Menta, A.K.; Kurzrock, R.; Kato, S. Therapeutic Implications of Epidermal Growth Factor Receptor (EGFR) in the Treatment of Metastatic Gastric/GEJ Cancer. Front. Oncol. 2020, 10, 1312. [CrossRef]

11. Blank, S.; Deck, C.; Dreikhausen, L.; Weichert, W.; Giese, N.; Falk, C.; Schmidt, T.; Ott, K. Angiogenic and growth factors in gastric cancer. J. Surg. Res. 2015, 194, 420-429. [CrossRef] [PubMed]

12. Bray, F.; Ferlay, J.; Soerjomataram, I.; Siegel, R.L.; Torre, L.A.; Jemal, A. Global cancer statistics 2018: GLOBOCAN estimates of incidence and mortality worldwide for 36 cancers in 185 countries. CA Cancer J. Clin. 2018, 68, 394-424. [CrossRef]

13. Machlowska, J.; Baj, J.; Sitarz, M.; Maciejewski, R.; Sitarz, R. Gastric Cancer: Epidemiology, Risk Factors, Classification, Genomic Characteristics and Treatment Strategies. Int. J. Mol. Sci. 2020, 21, 4012. [CrossRef] [PubMed]

14. Rawla, P.; Barsouk, A. Epidemiology of gastric cancer: Global trends, risk factors and prevention. Gastroenterol. Rev. 2019, 14, 26-38. [CrossRef]

15. Joshi, S.S.; Badgwell, B.D. Current treatment and recent progress in gastric cancer. CA Cancer J. Clin. 2021, 71, 264-279. [CrossRef] [PubMed]

16. Sunil, C.; Duraipandiyan, V.; Ignacimuthu, S.; Al-Dhabi, N.A. Antioxidant, free radical scavenging and liver protective effects of friedelin isolated from Azima tetracantha Lam. leaves. Food Chem. 2013, 139, 860-865. [CrossRef]

17. Antonisamy, P.; Duraipandiyan, V.; Ignacimuthu, S. Anti-inflammatory, analgesic and antipyretic effects of friedelin isolated from Azima tetracantha Lam. in mouse and rat models. J. Pharm. Pharmacol. 2011, 63, 1070-1077. [CrossRef] [PubMed]

18. Antonisamy, P.; Duraipandiyan, V.; Aravinthan, A.; Al-Dhabi, N.A.; Ignacimuthu, S.; Choi, K.C.; Kim, J.H. Protective effects of friedelin isolated from Azima tetracantha Lam. against ethanol-induced gastric ulcer in rats and possible underlying mechanisms. Eur. J. Pharmacol. 2015, 750, 167-175. [CrossRef]

19. Ortiz-Cruz, R.A.; Ramírez-Wong, B.; Ledesma-Osuna, A.I.; Torres-Chávez, P.I.; Sánchez-Machado, D.I.; Montaño-Leyva, B.; López-Cervantes, J.; Gutiérrez-Dorado, R. Effect of Extrusion Processing Conditions on the Phenolic Compound Content and Antioxidant Capacity of Sorghum (Sorghum bicolor (L.) Moench) Bran. Plant Foods Hum. Nutr. 2020, 75, 252-257. [CrossRef]

20. Wang, B.; Liu, L.; Huang, Q.; Luo, Y. Quantitative Assessment of Phenolic Acids, Flavonoids and Antioxidant Activities of Sixteen Jujube Cultivars from China. Plant Foods Hum. Nutr. 2020, 75, 154-160. [CrossRef] 
21. House, N.C.; Puthenparampil, D.; Malayil, D.; Narayanankutty, A. Variation in the polyphenol composition, antioxidant, and anticancer activity among different Amaranthus species. S. Afr. J. Bot. 2020, 135, 408-412. [CrossRef]

22. Ali, A.; Ali, A.; Husain Warsi, M.; Ahmad, W.; Tahir, A. Chemical characterization, antidiabetic and anticancer activities of Santolina chamaecyparissus. Saudi J. Biol. Sci. 2021, 28, 4575-4580. [CrossRef] [PubMed]

23. Job, J.T.; Rajagopal, R.; Alfarhan, A.; Narayanankutty, A. Borassus flabellifer Linn haustorium methanol extract mitigates fluoride-induced apoptosis by enhancing Nrf2/Haeme oxygenase 1-dependent glutathione metabolism in intestinal epithelial cells. Drug Chem. Toxicol. 2021. accepted. [CrossRef] [PubMed]

24. Bennett, R.N.; Mellon, F.A.; Rosa, E.A.S.; Perkins, L.; Kroon, P.A. Profiling Glucosinolates, Flavonoids, Alkaloids, and Other Secondary Metabolites in Tissues of Azima tetracantha L. (Salvadoraceae). J. Agric. Food Chem. 2004, 52, 5856-5862. [CrossRef] [PubMed]

25. Haraguchi, M.; Torii, S.; Matsuzawa, S.; Xie, Z.; Kitada, S.; Krajewski, S.; Yoshida, H.; Mak, T.W.; Reed, J.C. Apoptotic protease activating factor 1 (Apaf-1)-independent cell death suppression by Bcl-2. J. Exp. Med. 2000, 191, 1709-1720. [CrossRef]

26. Janssen, K.; Pohlmann, S.; Jänicke, R.U.; Schulze-Osthoff, K.; Fischer, U. Apaf-1 and caspase-9 deficiency prevents apoptosis in a Bax-controlled pathway and promotes clonogenic survival during paclitaxel treatment. Blood 2007, 110, 3662-3672. [CrossRef] [PubMed]

27. Kim, H.E.; Du, F.; Fang, M.; Wang, X. Formation of apoptosome is initiated by cytochrome induced dATP hydrolysis and subsequent nucleotide exchange on Apaf-1. Proc. Natl. Acad. Sci. USA 2005, 102, 17545-17550. [CrossRef]

28. Lewandowska, U.; Szewczyk, K.; Owczarek, K.; Hrabec, Z.; Podsędek, A.; Koziołkiewicz, M.; Hrabec, E. Flavanols from Japanese quince (Chaenomeles japonica) fruit inhibit human prostate and breast cancer cell line invasiveness and cause favorable changes in Bax/Bcl-2 mRNA ratio. Nutr. Cancer 2013, 65, 273-285. [CrossRef]

29. Joseph, S.V.; Edirisinghe, I.; Burton-Freeman, B.M. Fruit Polyphenols: A Review of Anti-inflammatory Effects in Humans. Crit. Rev. Food Sci. Nutr. 2016, 56, 419-444. [CrossRef]

30. Malayil, D.; Jose, B.; Narayanankutty, A.; Ramesh, V.; Rajagopal, R.; Alfarhan, A. Phytochemical profiling of Azima tetracantha Lam. leaf methanol extract and elucidation of its potential as a chain-breaking antioxidant, anti-inflammatory and anti-proliferative agent. Saudi J. Biol. Sci. 2021, 28, 6040-6044. [CrossRef] 